\title{
The Symbolic Power of the Ex Aceh Free Movement (GAM) Combatant as the Capital Owner (Toke)
}

\section{(A Case Study of Symbolic Power Relation between The Owner of Factory-Farmed Chicken Bussiness and The Community Members in Gampoeng Seuneubok, Nisam Sub-District, Aceh Utara Regency)}

\author{
Fakhrurrazi $^{1 *}$, Nirzalin ${ }^{1}$, Rizki Yunanda ${ }^{1}$ \\ ${ }^{1}$ Sociology Department, Faculty of Social And Political Sciences, Universitas Malikussaleh-Aceh Indonesia \\ "Corresponding author. Email: nirzalin@unimal.ac.id
}

\begin{abstract}
This article intends to describe the complexity of the reality of the factory-farmed chicken business being promoted by former GAM combatants in Gampoeng Seuneubok, Nisam Sub-District, North Aceh Regency. The practice of symbolic power imaged in the figure of former GAM is not only dominant in the political, religious and cultural sphere but also in the economic realm. In the economic realm, business ventures driven by former GAM combatants are running well, however, some of them are confused with the interests of the general public. One of the former combatants' business activities that undermines the public interest is chicken farming. The various complaints raised by residents to the village apparatus were unable to change the situation. The community did not have the courage to act more, they were only able to complain behind the owner of this chicken farm business. Meanwhile, village officials do not appear to have the courage to enforce the rules and norms of freedom of doing business without disturbing the village. The method used in achieving the above objectives is the ethnographic method. Data collection was carried out through Live In, observation, in-depth interviews, and document deconstruction. Although it is located in a settlement and disturbs the comfort of the life in the village, residents and village officials do not have the courage to take open resistance because of the labeling and symbols of the "former GAM".
\end{abstract}

Keywords: Symbolic Power, Toke (Capital Owner), Former Combatant, Aceh Free Movement (GAM), Gampong (Villange)

\section{INTRODUCTION}

The fundamental problems faced by the Indonesian people today are the high levels of poverty and unemployment. Apart from that, Indonesia is also a country that often experiences external shocks one after another, with earthquakes, floods, droughts and forest fires. Another external blow that is directly felt by the wider community at this time is the Covid 19 pandemic which has increased the rupiah exchange rate sharply, which has been accompanied by an increase in the price of food needs such as rice, corn, milk and cooking oil. With a population of more than 220 million and still growing, Indonesia should be able to achieve food independence and security in a sustainable manner (Purnomo, 2015).

The armed conflict between the Indonesian government and the Free Aceh Movement that occurred between 1976 and 2005, staged many social problems (Nirzalin, 2012: 107-123). Violence, poverty, loss of freedom, and trauma are a number of social problems that have not been fully resolved to date. At the grassroots level, the public's fear of the power of violence possessed by parties, both the Indonesian government security apparatus (TNI / Polri) and GAM 
(Free Aceh Movement) combatants, is very deep. In fact, this fear is passed on through generations so that psychological and sociological trauma experience continuity and permanence.

The peace was successfully agreed upon by the parties, on August 15, 2005 in Helsinki, Finland. This gave hopes to many elements of communities, especially rural communities, that life would return to normal. Violence ends, security becomes stable, the economy is growing, politics has become democratic and civilized, and fear has turned into a celebration of happiness, and more importantly, the space for equal effort for ordinary people and former combatants.

After the conflict, the Indonesian government launched a reintegration program of former GAM (Free Aceh Movement) combatants into civil society in Aceh. The reintegration program under the policy of the Aceh Reintegration Agency (BRA) has been ongoing from 2006 to 2020. This Reintegration program, in addition to creating stability in the economic income of former combatants, is also changing their mentality from a military mentality to a civilian one. However, this program has not completely been able to change the mentality of former combatants in society. On the other hand, the symbolic profile of former combatants who are portrayed as strong, courageous, capable of regulating and committing violence in the eyes of Acehnese civil society, especially in rural areas, encourages an attitude of reluctance and fear of intersecting with their interests.

However, in addition to being carried out in areas far from residential areas, the maintenance of broilers is also done in residential areas. One of the chicken farms which is located in residential areas is a chicken business in Gampoeng Seuneubok, Nisam District, North Aceh Regency. This chicken farm business which is located in Bakti ABRI Hamlet belongs to a former GAM combatant. The farm has three large cages and is located next to residential areas.

Because it is a large business and is cultivated intensively, the results of this chicken breeding business are able to meet the supply needs of chicken meat for the Lhokseumawe and North Aceh markets. In terms of chicken meat supply, the existence of this chicken farm business has a positive impact in reducing dependence on the supply of chicken for the City of Lhokseumawe and North Aceh. However, ecologically, the existence of this chicken business disturbs the comfort of the surrounding community. The unpleasant smell and green flies that really disturb the comfort of the residents are the problems that the local residents have to deal with.

The various complaints raised by residents to the village apparatus were unable to change the situation. People do not dare to act more; they are only able to complain behind the owner of this chicken farm business. Meanwhile, village officials do not appear to have the courage to enforce the rules and norms of freedom of business that do not disturb the comfort of the village. Departing from this reality, this study is interested in knowing and understanding why the chicken farm business promoted by former GAM combatants in Gampoeng Seuneubok, Nisam District, North Aceh Regency, even though it is located in a residential area and disturbs comfort, residents and village officials do not dare to take open resistance.

The absence of response to community complaints by farm owners and the absence of the ability of the community to fight directly indicate that people cannot do much and do things on their own individual way to channel their feelings of protest and resentment. Therefore, the community began to fight indirectly in order to reject the existence of this farming activity by poisoning and stealing the chickens at the farm. Thus, it is interesting to understand the Symbolic Power of Toke Ex-Combatants of the Free Aceh Movement, a case study of the symbolic power relationship of beef chickens farm owners and communities in Gampoeng Seuneubok, Nisam District, North Aceh District.

\section{CONCEPT OF HABITUS AND SYMBOLIC POWER AS EX-GAM TOKE}

In observing and analyzing the situation in Seunebok Village, this article looks at the symbolic power that former GAM has in carrying out business activities of chicken breeders. According to Foucault in Haryatmoko, 2016, power fascinates people that they are willing to suffer for the sake of power. Many people usually talk about power and the state, now of course power is with the subject. Power does not refer to the general system of domination by one group over another, but the variety of power relations. Power is not an institution, and is not a structure, nor is it power that is owned; but the name given to a strategic complex in a society. Power is everywhere does not mean it is allencompassing, but power comes from everywhere. Because one of them is the power relationship that cannot be separated from the relationship in the economic process (Haryatmoko. 2016).

Bordieu in Haryatmoko (2016) states that in every society, there is always someone who controls and those who are controlled. This domination relationship depends on the situation, resources (capital) and the strategy of the actors. The mapping of power relations is based on the ownership of capitals and the composition of these capitals. Economic capital is a resource that can be a mean of production and a mean of finance. This capital is most easily converted to other capitals. Meanwhile, symbolic capital produces symbolic power. Therefore, symbolic power often requires symbols of power such as position, high status and well-known 
family names. Symbolic capital is all forms of recognition by groups, whether institutional or not, which in turn will form the structure of the social sphere. "Symbolic Capital" must be understood as economic or political capital which is denied, misrecognized and therefore acknowledged that it is legitimate to exist under certain conditions.

The symbolic power possessed by the ex-GAM toke is a problem that greatly gives people insecurity and comfort. Second, the symbol of ex-GAM being saved by a chicken farmer entrepreneur creates fear of the community around the chicken coop, so that the discomfort they receive is unable to resist, especially regarding the cleanliness and discomfort of the community due to the effect of the bad smell from the chicken coop.

This reality makes symbolic power an arena of struggle for former combatants to run the chicken farming business. The concept of the arena of struggle is very decisive because in all societies there is the ones who control and who are controlled. Thus, it is not surprising that, empirically, the case of ex-GAM toke power in running the beef chicken business. This fact is a differentiator from previous studies. This study specifically uses an ethnographic approach in examining the issue of the symbolic power of the ex-GAM toke and the relationship between symbolic power and the owners of beef chickens.

\section{METHODS}

This research was conducted in the village of Seuneubok, Nisam District, North Aceh Regency, Aceh Province. This location was chosen because the people of Gampoeng Seuneubok did not have the courage to take open resistance against toke (Capital Owner) of a chicken farm whose business disturbed their comfort. Second, identify what motivates toke of chicken farm to not respond to community complaints about the inconvenience caused by their business. The same is done by Gampoeng (village) officials.

During data collection, the writer used the live in method. The main objective of this method is that the researcher is able to build a sociological imagination about the patterns of social practice of the people who are the research subjects. Hence, through this method the researcher lives in one of the residents' houses, participates in their discussions, listens to the gossip they are doing, worships with them and is involved in certain jobs carried out by members of the community, especially the target as informants.

The work is like participating in cutting grass for livestock, health care and harvesting rice. Through this strategy, not only the sociological imagination is awakened but also the close and sibling emotional relationship between the researcher and the community.
This facilitates the process of observing and determining informants for in-depth interviews. This process facilitates researchers in digging up as much information as possible.

The research informants in this study were the people who were directly involved with the problem of bad smell with the cage as the main informants (key informants). Meanwhile, community leaders who became the source of research information (informants) were Geuchiek (Village Head), Tuha 4 (Village Representative Body), Teungku Imeum and Youth Figures including the owners of the livestock business. Apart from them, this study will also interview several randomly selected community members. The determination of community members is usually carried out through an intensive process of interaction between researchers and the community

\section{SEUNEUBOK: FROM HARMONIOUS SOCIETY TO RESISTANCE AND TABLES}

Seuneubok is a Gampoeng (village) located in Nisam District, North Aceh Regency. The population of this village is 587 people with 150 families. Nearly $99 \%$ of the population is ethnic Acehnese, while the other $1 \%$ is immigrants (Seuneubok Gampoeng Demography, 2019). As with most agricultural areas, the village geography of Seuneubok is agricultural geography. Therefore, the main source of economic income for the people rests on the agricultural sector. Most of the people work as farmers, reaching 150 people, the remaining 55 people work as laborers / manual laborers, 19 traders, 27 people work as breeders / planters, 8 workshop workers, 16 people work as carpenters, craftsmen / home industries numbering 11 people, 12 people working as entrepreneurs, and 14 people as PNS / TNI / POLRI. (Source: Seuneubok Gampoeng Monograph Data, 2019). This geographical reality places the people of Seuneubok as a farming community. From this agriculture they start a life, make a living and depend on life.

This historical fragment of the agricultural economy, although not entirely, was interrupted during the period of intense conflict between the Indonesian government and the Free Aceh Movement in 1976-2005. This initial period, the people of Seuneubok lived in harmony without any problems and friction between the villagers. However, after the peace of the Free Aceh Movement (GAM), efforts began to emerge from former GAM combatants. One of them is chicken farm. One of the impacts caused by chicken farming on the environment around the community is the unpleasant smell and the appearance of fly infestation. One of the factors causing this odor is the high ammonia gas content. This unpleasant smell can be found on poultry farms in Dusun Bakti Abri. 
The impact of this unpleasant smell is one of the reasons for the community, that the chicken farm located in the area of the villagers' homes is something that is considered disturbing the comfort of the people of Seuneubok village; this has led to resistance (resistance) in the community. When the breeding season arrives, for two months in which the community has already put up with resistance, one form of the way to do the defense is by filing a direct protest, and some report to the geuchiek to tell them not to farm in that place, not to throw the carcasses of the chicken into the river and ask the coop owner not to collect chicken manure near the farm. The action was carried out after nearly two months of warning, but did not meet the demands of the community.

The indifference of the owner of the chicken farm in Bakti Abri Hamlet, Seuneubok village, Nisam District, has troubled the community. This is because since the existence of this farm, it has caused a lot of flies, a bad smell due to the chicken manure piled up in the coop. Furthermore, chicken carcasses are also often thrown into the river so that it disturbs the community when washing, bathing, or performing ablution.

According to Safril (in Purnomo, et al. 2015), the number of chicken farming businesses in the community is felt to be disturbing residents, especially chicken farms which are located close to residential areas. Many breeders ignore handling waste from their farms. The impact that can be caused by chicken farming is the smell, the emergence of flies and the worry of spreading the bird flu virus (H5NI).

As a result of the bad impact experienced by the community with the existence of a chicken farm in Bakti Abri Hamlet, the community made resistance. One of the people's resistance is to protest by asking the owner of the farm to fulfill some of their demands, such as not raising livestock in the location because of the community residential area, not piling up chicken manure near the farm because it has created a bad smell and lots of flies, and does not throw away the carcasses. poultry to the river because it can interfere with community activities.

According to Pratiwi (in purnomo, et al. 2015), the feces produced by chickens cause an odor that can disturb the health of the community around the cage, especially the psychomotic symptoms that the public complains about. Psychomatic is a physical disorder from excessive psychological activity in reacting to emotions such as dizziness, nausea, vomiting, lack of appetite and sleep disorders. The disturbance experienced by the community with the existence of this farm is that it causes lots of flies so that they lose their appetite.

\section{THERE IS NO COMMUNITY POWER AND EX-GAM HARD POWER}

The people of Gampong Seuneubok, especially Dusun Bakti Abri, do not dare to fight against livestock business owners because they have hard power, which is a direct form of empowering them, either with a coercive approach or reward (giving gifts) to the community. Even during the theft and poisoning of broilers, the Nisam Police and Koramil came to the farm to investigate the case. They even asked the public regarding the incident. This causes people to be afraid to protest or fight against it, worried that they will be accused of the incident. This caused them to remain silent so they would not have to deal with the former GAM livestock business owner.

The resistance movement was not followed by the masses by the masses. Only a small part of the community dared to fight, especially in Bakti Abri Hamlet. Meanwhile, other people in the hamlet do not dare to fight because they depend on living by earning a living on plantations, agriculture, livestock from the toke business, so they choose to remain silent, and they are also afraid of losing their jobs if they protest against it. As a result of the lack of community protests, the community's demands to abolish livestock were not fulfilled, even business owners considered the problem not a serious problem, because only a small part of the community protested.

According to Wahyu Ningsih (2012: 3), misunderstanding and lack of trust are interrelated. Organizational members resist change when they do not understand its implications and think that change may only cost more than it can get. Such a situation occurs when there is no trust between the party collecting the changes and the members of the organization.

There is no strength to resist. This is because the people who are fighting back only get support from a small group of people in Seuneubok Village, especially the dusu themselves, especially Dusun Bakti Abri, besides that no one dares to fight for fear of losing their job or being arrested by the police. They do not get support from the community or other residents, because the other hamlet people do not care less about livestock, because it is far from their place and does not disturb their own comfort. Apart from that there is no support from the gampong apparatus, the majority of the gampong apparatus choose to remain silent and think that the establishment of a farm is not wrong, because standing on their own land has a letter, and other people in the hamlet also do not protest so this cannot be done to eliminate the farm. Powerlessness (Inertia). Every organization can experience a certain level of helplessness and therefore trying to maintain its status Quo. Change does require effort, often very serious 
efforts and exhaustion can occur (Wahyu Ningsih, 2012: 3).

\section{CONCLUSION}

The practice of symbolic power imaged in the figure of former GAM is not only dominant in the political, religious and cultural sphere but also in the economic realm. In the economic sphere, business ventures driven by former GAM combatants are running well, although they are confused with the interests of the general public. The resistance made by the community against the owners of chicken farms in Gampong Seuneubok, Nisam District, was by filing open protests by several people in Bakti Abri Hamlet who asked the farm to be closed because it had a bad impact on the community. However, the absence of the entire community is the cause of the failure of community resistance to this business. Hard Power, which is owned by a former GAM entrepreneur, is able to influence other communities, so most people don't want to have anything to do with it, let alone those who work at the farm owner's place of business. So that some are afraid of losing their jobs. In addition, the community's helplessness to fight back stems from the absence of support from the entire community and village government officials.

This reality proves that the symbolic power possessed by former GAM has a strategic and significant position in the bargaining process to run a business in the community. The fanaticism of some of the community towards the ex-GAM toke has made the main capital owned by breeders and entrepreneurs in running their businesses despite the pressure from the community. Through this symbolic capital, it can dampen the mass action movements of the community that are not well organized so that resistance to closing chicken farms can be broken.

\section{REFERENCES}

Nirzalin N. 2012. Islamic Shari'a Politics And Teungku Dayah's Political Authority Crisis In Aceh. Journal OF Government AND Politics Volume 3 (2) 211234

Purnomo, dkk. 2015. Analisis Bau Limbah Peternakan Ayam Di Pemukiman Terhadap Gangguan Psikosomatik Masyarakat Sekitar Kandang Di Desa Sei Lembu Makmur. Jurnal Dinamika Lingkungan Indonesia, Juli 2015, P 57-63, Volume 3, Nomor 1.

Haryatmoko, 2016. Membongkar Rezim Kepastian Pemikiran Kritis Post-Strukturalis. Penerbit Kanisius

Wahyuningsih .2012. Sistem Sosial Indonesia. Jakarta: Raja Grafindo Persada
Moleong, Lexy J. 2014. Metodologi Penelitian Kualitatif. Edisi Revisi. Bandung: Rosda Karya

Rasyaf, M. 1981. Manajemen Peternakan Ayam Petelur. Jakarta; penebar Swadaya.

Sugiyono. 2007. Memahami Penelitian Kualitatif. Bandung: Alfabeta 